\title{
EFFECT OF BRAND AMBASSADOR ENDORSEMENT AND SALES PERFORMANCE OF PEPSI-COLA IN NASARAWA STATE
}

\author{
By \\ 1ONYEMOBI, Uchenna Kessington* \\ ${ }^{2}$ OLOFU, Clifmanic Godwin
}

\begin{abstract}
${ }^{1}$ Centre for Foundation and Interdisciplinary Studies (CFIS), Baze University, Abuja, FCT Nigeria ucheonyemobi17@gmail.com, +1 (470) 547 4057, +234 9028282872 (Corresponding Author)

2Department of Business Administration, Nasarawa State University, Keffi, Nigeria clifmanico@gmail.com, 08032343105,09154442290
\end{abstract}

\begin{abstract}
The study investigated effect of brand ambassador endorsement and sales performance of PepsiCola in Nasarawa State. The study adopted survey research design, with a study population of 203 respondents. Data for the study was primarily sourced via a questionnaire, structured with open and close ended questions. Data collected were regressed and findings revealed that Brand Ambassador's credibility, popularity, acceptance and integrity severally have significant relationships with sales performance of Pepsi Cola in Nasarawa State. The study therefore, recognises that Brand Ambassador's credibility, popularity, acceptance and integrity have significant relationship with sales performance of Pepsi Cola in Nasarawa State. However, suggestions from the open ended section of the questionnaire led to a recommendation that Pepsi-Cola, a fairly underperforming firm in the carbonated drink industry should invest hugely on other promotional and advertising platforms that will root there product in the heart of the market, with minimal focus on brand ambassadorship, due to the expensive nature of the brand ambassadorship model of brand promotion.
\end{abstract}

Keywords: Brand, Ambassador, Endorsement, Brand Image, Sales Performance

c) 2020 the Author(s). Published by OASIS Journals. Open access under CC BY-NC-ND License

\section{Introduction}

Presently, the level of competition in consumer goods market is high covering new and existing products. Achieving sales and maximizing profitability depends on how effectively firm seeks to use several marketing promotional tools to strategically attract and convince consumers. Out of these promotional tools is advertising, which according to Opuni et al. (2014) is used to create awareness about a particular product. But as a result of congestion of advertising contents and consumers being on the regular media platforms such as television, radio, newspapers, billboards and websites, sellers are now adopting new approach to promotion using celebrity 
endorsements. There is the tendency that consumers may want to associate successful products with celebrities, especially celebrities within the entertainment industry. In turn, such association enthuses buyers to seamlessly associate themselves with such celebrity endorsed products.

In consequence, celebrities are bound to be useful in promoting brands through the process of endorsement (Bhasin, 2018). Thus, corporations invest huge amounts in convincing celebrities to endorse their products/brands (Deshwal, 2015). Meanwhile, Pughazhendi and Ravindran (2012) stressed that endorsers are referred to as "any individual who enjoys public recognition and who uses this recognition on behalf of consumer goods by appearing with it in an advertisement". Firms often use this type of promotional strategy to communicate new product attributes to potential customers and retaining existing ones. Currently, this form of promotional approach seems to be increasingly adopted across all types of products in media presentation.

Erdogan (2012) asserted that the level of intense competition as generated by celebrity endorsement will inevitably catalyse differentiation and strengthen brand image of products in the marketplace. Thus, firms employing celebrity endorsements should seek to fulfil the objectives of familiarity, relevance, esteem and differentiation in relation to endorsed products. By differentiation, celebrities should stand out amongst others. By esteem, celebrities' credibility must be considered socially acceptable. By relevance, there should be a link and connectivity between endorsing celebrities and the products, as well as the targeted audience. And by familiarity, the endorser/celebrity is easily recognized by the target market (Lalwani, 2011).

In consonance, Vipul (2011) opined that the success of any brand through celebrity endorsement can only be achieved with the cumulative of Celebrity-Target Audience Match, Celebrity Values, Costs of Acquiring the Celebrity, Celebrity Regional Appeal Factors, Celebrity-Product Match, Celebrity Controversy Risk, Celebrity Popularity, Celebrity Availability, Celebrity Physical Attractiveness and Celebrity Credibility. Furthermore, Khan et al., (2016) reported that consumers are more committed to products when they trust that a celebrity is associated with the product. Further 
studies are of similar view that involving a celebrity in an advertisement yields powerful results on credibility, brand recall and acceptability of that advertisement, ultimately leading to increased sales. (Menon et al., 2001; Laffety \& Golsmith, 1999).

\section{Statement of Problem}

Fierce competition among firms has compelled a wave of strategies that will effectively and variously position them at positions of advantage over competing brands and firms; one of these strategies is Brand Ambassadorship endorsement. Brand Ambassador Endorsement is a strategy whereby public figures and celebrities with huge fan base are contracted to be the face of a product, for the purpose of bringing the product close the such celebrities' fan base. Pepsi Cola, understanding the importance of this useful promotional model, has contracted a number of celebrity endorsements from different industries like the movie, music and sports industries.

Currently, on the list of Pepsi's celebrity endorsement program are celebrities like Wizkid (music artist), Tiwa Savage (music artist), Alex Iwobi (footballer), among others. This endorsements are aimed at instigating patronage which will ripple on their sales performance, Regardless of their robust Celebrity endorsement program, Pepsi is still not market leader and is observed to also struggle with sales just as peers in the beverage industry. This, therefore instigated this study.

\section{Research Question}

The following questions are used to achieve the objectives of this study;

i. What is the effect of brand ambassadors' credibility on sales performance of Pepsi Cola in Nasarawa State?

ii. What is the effect of brand ambassadors' popularity on sales performance of Pepsi Cola in Nasarawa State?

iii. How will brand ambassadors' acceptance impact sales performance of Pepsi Cola in Nasarawa State?

iv. What is the relationship between brand ambassadors integrity and sales performance of Pepsi Cola in Nasarawa State? 


\section{Research Objective}

The broad objective the study was to achieve is to determine the effect of celebrity endorsements on sales performance of Pepsi Cola, Nasarawa State. However, the following under listed are the specific objectives of the study:

i. To determine the effect of brand ambassadors' credibility on sales performance of Pepsi Cola in Nasarawa State.

ii. To examine the effect of brand ambassadors' popularity on sales performance of Pepsi Cola in Nasarawa State.

iii. To investigate the effect of brand ambassadors' acceptance on sales performance of Pepsi Cola in Nasarawa State.

iv. To investigate the effect of brand ambassadors' integrity on sales performance of Pepsi Cola in Nasarawa State.

\section{Statement of Hypothesis}

The following are the null hypotheses tested for this study:

Ho1: There is no significant effect of brand ambassadors' credibility on sales performance.

Ho2: There is no significant effect of brand ambassadors' popularity on sales performance.

Ho3: There is no significant effect of brand ambassadors' acceptance on sales performance.

Ho4: Brand ambassadors' integrity has no significant effect on sales performance.

\section{Scope of the Study}

The study covers effect of brand ambassadors' endorsement on sales performance of Pepsi-Cola within Nasarawa State, with particular reference to credibility, popularity, acceptance and integrity of brand ambassadors as independent variables of the study while sales performance of Pepsi Cola is the dependent variable of the study. 


\section{Significance of the Study}

Beneficiaries of this study are majorly four. Those in the academia, Pepsi, the government and researchers.

The study will be of benefit to the academics, in that, it will serve as an empirical resource wherein academics can draw reference from, even for future studies. Then, this study will be of immense importance to Pepsi (and indeed other for-profit organisations), as they can draw inferences from recommendations in this work to further help device ways to position their brands within their competing environments. Finally, this study will offer a fresh pool of knowledge for researchers.

\section{Operational Definition of Terms}

Brand Ambassadors: According to this study, brand ambassador could also mean celebrity endorser, which connotes a contracted person, hired to represent the brand image in the eyes of his/her fan base.

\section{Literature Review}

\section{Overview of Brand Ambassadors and Brand Ambassador Endorsers}

Before the concepts of celebrity endorsers and brand ambassadors can be explored, it is important to differentiate between self-branding and celebrity branding:

1. Self-branding, also referred to as personal branding, is the process of developing a symbol that is created around an individual's career or name. This symbol is used to express and communicate the individual's skills, personality and values in order to develop a personal brand which will develop a reputation to grow a network in a way that interest others (Lake, 2014).

2. Celebrity branding, also referred to as celebrity endorsement advertising (celebrity endorsements) is defined as engaging the fame of a well-known person to promote a product or service. The celebrities market the products and services through television or radio ads and large event appearances. Essentially, celebrities are employed in marketing campaigns to drive up sales and ultimately have a positive impact on profits (Grimsley, 2014) 


\section{The Concept - Brand Ambassador}

Ambroise, Pantin-Sohier, Valette-Florence, Albert, (2014) defined a brand ambassador as someone who is passionate about an organization or its brand, and engages in activities, often on social media, that provide brand meaning for consumers. (Ambroise 2014) defined Brand ambassadors as organizational spokespeople humanizing the brand and facilitating relational connections with an organization. McKinney (2014) defined a brand ambassador as someone who represents a brand in a positive way. In essence, it is the duty of the brand ambassador to express the message of a company to consumers.

Most organisations and brands use celebrities in their marketing in hopes that it will drive up sales and ultimately have a positive impact on their profits. Westberg (2010) defined a brand ambassador as an individual who constitutes a credible testimony of distinctive character, and can by means of the word-of-mouth effect influence others through their networks and relationships. (Rogers and Cartano, 1962). Effectively, a brand ambassador is a mediator between internal and external brand management. Brand ambassadors can exert a significant impact on customer perception of brands and organizations - in general, brand ambassadors are brand representatives who confer credibility on brands using their social reputation (Goutam, 2013; Harris and De Chernatony, 2001).

\section{Different Kinds of Brand Ambassadors}

Morin-Van Dam (2014) distinguishes between four different kinds of brand ambassadors, namely the goodwill ambassador, promotional models, testimonials and brand advocates.

\section{The goodwill Ambassador}

The goodwill ambassador is a celebrity who supports brands (especially non-profit making and cause-related brands) by exploiting the celebrity's reputation and talent (Maguwu, 2014). These celebrities are often used by humanitarian organisations to assist in generating funding, donations as well as to encourage volunteers to participate in the organisation's activities. Examples of goodwill ambassadors include 
Katy Perry and David Beckham who are UNICEF ambassadors - they use their fame to focus the world's attention on the needs of children (UNICEF, 2014).

Promotional Models. Promotional brand ambassadors refer to commercial brands who take advantage of celebrities' fame to market their products (Maguwu, 2014). Catherine Zeta-Jones is an example, as she made \$20 million from endorsements for the cell phone company T-mobile (Enstars, 2014).

Testimonial. The testimonial is a common advertising method where a consumer (as opposed to the manufacturer or creator) attests to the effectiveness and explains the benefits of the product. Celebrity testimonials are regarded as a powerful technique as the product or service promoted is easily identifiable with the celebrity's image or speciality (Joseph, 2014). On her television show, keeping up with the Kardashians, Kim Kardashian underwent LASIK eye surgery from Robert Maloney (Maloney Vision Institute, 2011). Then, Kim became a celebrity endorser for the Maloney Vision Institute stating, "The next day I woke up and I could see so clearly. I can see well than I ever have before. I just love everything that's going on right now" (Maloney Vision Institute, 2011)

\section{Brand Advocates}

Trevor (2013) defines a brand advocate as "a consumer who influences other consumers' purchasing decisions, interacts with measurable consistency within their networks to promote a brand, generates online and offline word of mouth marketing, and is an integral component of every marketing and advertising objective." In 2008, Starbucks developed the advocate-driven idea tank, MyStarbuckIdea.com where consumers can submit ideas and inputs for new products and coffees. This platform enabled Starbucks to have millions of fans as soon as a new product is launched (Petersen, 2013).

\section{The Concept - Endorsement}

Ateke, (2013) defined endorsement as a testimonial in marketing communication which could be a written or spoken statement in favour of a product, usually given by 
a party other than the maker of the product. Endorsement is a medium of brand communication in which an individual or organisation acts as the brand's spokesperson and certifies the brand's claims and position by extending his/her/its personality, popularity, status in the society or expertise in a field to the brand. It is the act of giving ones public approval to someone or something; especially a recommendation of a product in a marketing communication. Melford \& Nwulu, (2015) defined brand endorsement as an advertising strategy whereby companies use people of public recognition as spokespersons for their products. Celebrity endorsement is a common phenomenon in today's market-place where celebrities as well-known personalities are gaining more importance and fan following. McCracken, (1989) defined brand endorsement as a form of brand or advertising campaign that involves well known persons using their fame to promote products (or services). According to Friedman and Friedman (1979) in McCracken (1989), a brand ambassador is any individual, character or organization who enjoys public recognition and who uses this recognition on behalf of a consumer good (or service) by appearing with it, or speaking in support of its claim in an advertisement.

\section{The Concept - Brand Endorsement}

(Melford \& Nwulu, 2015) posit that, as competition to capture consumers' attention and interest for brands intensifies, marketers have developed better advertising strategies to get the consumer's attention, create interest, arouse desire and instigate purchase action. Engaging celebrities to serve as spokespersons for brands is one of such strategies. (Schlecht, 2003) defined brand ambassadors as persons who are recognized by a large share of a certain group of people primarily because of the publicity associated with their lives. Austad, (2004) consider brand ambassadors as persons with prominent social profile as much as enjoy appreciable levels of public attention and influence in the society. The term is often synonymous with wealth, impliedly associated with popular appeal and prominence in a particular field, and easily recognized by the general public. 


\section{The Concept - Brand Image}

A brand is the name, term, sign, symbol, design or any other feature that identifies seller's products and distinguishes it from those of other sellers (Watkins, 2006; Kotler et al, 1996; Doyle, 1994; Aaker, 1991) It is an identifiable entity that makes specific promises of value; and is often the most valuable asset a firm can own (Aaker, 1991). On the one hand, a brand is usually invented when marketing adds value to a certain product in the process of distinguishing it from other products with similar features, benefits and values (Pearson, 2005). Branding on the other hand is the expression of the essential truth or value of an organisation and its products that distinguish it from the competition (Aaker, 1996). It is communicated through features, values, attributes among other qualities that clarifies what a particular brand is; and what it is not (Aaker, 1996).

Brand image is thus the consumer's perception of a brand and is measured as the brand associations held in consumer's memory (Keller, 1993); it is the reasoned or emotional perception consumers attach to specific brands (Dobni \& Zinkhan, 1990). Brand image can also be seen as the totality of consumers' perceptions about the brand, or how they see it, which may not be the same with the brand identity (Dobni \& Zinkhan, 1990). A brand image consists of functional and symbolic brand beliefs. It is a strong, favorable and unique brand association in recognition, which will result in positive attitude, perceived quality and positive overall effect (Keller, 2003). Basically, any specific information existing in the minds of customers with respect to a brand is relevant as an image element (Bondesson, 2012).

Keller, (2003) also states that brand image has been widely accepted in literature as the perception existing in the memory of the customer. When a customer can recognize a product brand, it means that they have combined the symbolic value and the willingness to own the product as well. Keller (2003) further states that high level of brand awareness and positive brand image will increase brand choice probability of customers, leading to increase customer loyalty and lower marketing costs. It is thus important for companies to create great and effective brand image, since a strong brand image elicits positive attitude from consumers and results to higher profit stream, either in the long or short terms (Hussain, 2007). If a firm fails to provide a 
positive and strong brand image, it may directly or indirectly affect the consumers' decision making; as consumers may shift to competitors that offer better experience. In order to achieve goals associated with product and brand management, it is important to build a strong brand. Several metrics have been put forward in the past few decades as measures of brand image by renowned authorities in marketing in general, and branding in particular. However, this paper limits itself to the examination of brand awareness, brand distinction, brand personality and brand prestige as measures of brand image.

\section{The Concept - Brand Awareness}

Brand awareness describes the extent to which a brand is recognized by potential customers, and is correctly linked with a particular product. Brand awareness is the primary goal of advertising at the introduction stage of a new product in the product life cycle. Consumers buy a familiar brand because they are comfortable with it or because they assume that a familiar brand is probably reliable and of reasonable quality (Aaker, 1991). Brand awareness also refers to an ability to identify, recognize, or recall a brand in a certain product category (Keller, 1993; Aaker, 1991). Tangible attributes of branding, such as a brand name, logo, symbol, icon, and metaphor facilitate consumer's awareness of a brand (Neumeier, 2006). Also, advertising and positive word-of mouth regarding a brand may enhance brand awareness, which plays an important role in consumer decision-making (Aaker, 2007, 1996; Pitta \& Katsanis, 1995). A consumer may easily patronize one brand or the other because he/she frequently sees the brand names and logos promoted on television or billboards, and has experience with the brands (Cho, 2011).

Also, Cho (2011) state that a positive reputation for a brand may increase the level of awareness, and foster the consumer's interests in the brand. Brand recognition is thus important for a new brand; while brand recall is vital for a well-known brand (Aaker, 1996; Aaker, 1991). Although brand recall frequently leads to purchase decisions; disliked or hated brand could be the first recalled brand in consumers' minds, due to pessimistic perceptions of the brand formed by negative past experiences with the brand (Kim, et. al., 2003). Thus, it can be stated that brand awareness is the degree to 
which consumers remember the brand or are able to recall the brand from memory; and is measured through brand recall or brand recognition. Brand recognition reflects the ability of consumers to confirm prior exposure to a brand; or the ability of consumers to retrieve the brand from memory when given the product category, or customers' needs fulfilled by the category, or some other types of probe as a cue (Kim et al, 2003).

\section{The Concept - Brand Distinction}

Brand distinction is a marketing strategy that aims to make a brand occupy a unique position relative to competing brands, in the mind of the customers. Every firm has a value proposition that defines how its brand is different from those of other firms and why consumers should patronize it. Also, every firm has a brand, strong or weak, which must be clearly differentiated from the competition since consumers have to distinguish the firm's brand from the competition. Brand distinction is a phenomenon that must occur whether a firm is proactive, reactive or passive about evolving a distinctive position in the minds of the consumers (Ateke \& Elvis, 2013; Nwulu \& Ateke, 2013).

However, a firm can positively influence the perception of its target market towards its brand through enlightened strategic actions. Brand awareness is important for all brands; however, high brand awareness without an understanding of what sets the brand apart from those of the competition does the firm virtually no good. This distinction as to why a firm's brand is unique in its category is also referred to as the Unique Selling Proposition (USP); and is usually achieved through positioning. Positioning defines how a firm differentiates itself in the minds of the consumer. (Trout \& Rivkin, 2010). It is the process by which a firm seeks to create an image or identity for its product, brand or the firm itself in the minds of their target market. It involves carving a niche in the minds of the consumers in a way that a firm or its product is perceived to assist consumers to solve their problems better than competing firms (Nwulu \& Ateke, 2013).

Positioning may also be seen as a marketing strategy that aims to make a brand occupy a distinct position in the minds of target consumers, as distinct from those of 
competing brands. A firm, its product or brand must have a unique position in order to survive in present day competitive markets, and effective brand distinction is contingent upon identifying and communicating a brand's uniqueness, differentiation and verifiable values (Nwulu \& Ateke, 2013). Firms apply this strategy either by emphasizing the distinguishing features of the brand, or by creating a suitable image through marketing communication.

\section{The Concept - Brand Personality}

Brand personality is a set of human characteristics that are attributed to a brand name (Aaker, 1997). Also, it can be conceived as human traits or characteristics associated with a given brand name. Common characteristics or traits represented include uniqueness, sincerity, intellectualism, competence, excitement and sophistication (Business Dictionary, 2014). Brand personality gives consumers something with which they can relate. It is something to which the consumers can relate, and an effective brand will increase its brand equity by having a consistent set of traits (Investopedia, 2014). This is the value that a brand gains, aside from its functional benefits.

There are five main dimensions of brand personality; sincerity, excitement, competence, sophistication and ruggedness (Aaker, 1997). Brand personality is part of how consumers perceive the brand and how the brand differentiates itself from the competition. Accurately understanding brand personality is important to brand success (Aaker, 1997). Also, being able to measure something as important, yet as intangible as brand personality enables brand owners to ask important questions that can strengthen their competitive advantage (Edelhart, 2014). Understanding brand personality also helps select the most appropriate message and media, or more effective and suitable sponsorships or partnerships (Edelhart, 2014). Ultimately, understanding a brand personality enables the brand owner to deliver a consistent brand experience that connects with consumers and leaves a deeper and more sustainable impression (Aaker, 1997). Brand personality characteristics often suggest a brand's latent appeal, and when identified and cultivated, they can effectively guide the creative tone of communications. Having a good grasp of how consumers perceive 
a brand is very important; even as consumers have shown preference for branded products with reputable image in almost every product category.

While there is a plethora of reasons consumers buy the brands they favour, the image of the brand cannot be overlooked (Wysong, 2012). Consumers usually buy a brand because they identify with it or because it has an image distinct from others. Marketers must therefore continually examine how consumers perceive their brand's image; and to help understand brand image perceptions, researchers have turned to the concept of brand personality within the last fifteen years (Wysong et al, 2012). With this approach, consumers are adjudged to think of a brand as a person by ascribing human characteristics such as honesty, wholesomeness, daringness, upper-class, toughness, ruggedness, sophistication, competence etc. to the brand (Wysong et al, 2012).

\section{The Concept - Brand Prestige}

Brand prestige can be defined as high reputation of a brand achieved through the brand's success in meeting the requirements of the consumers, or effectively solving their problems. An important decision brand managers face is how to position a brand to take advantage of its distinctive appeal, differentiate it from competitors, and resonate with target consumers (Hanzee \& Taghipourian, 2012). Although brands can be positioned in several ways (Ateke \& Elvis, 2013; Bhasin, 2011; Trout \& Rivkin, 2010; Aaker \& Myers, 1987; Aaker \& Shansby, 1982), a basic distinction is a prestige versus a functional brand concept (Monga \& John, 2010).

Prestige is a subjective evaluative judgment about the high social status of people or inanimate objects, such as brands. Research has shown that evaluative judgments are often followed by emotional reactions (Bagozzi, 1999).

Also, Shenkar and Yuchtman-Yaar (1997) point out that an important source of prestige judgments is prestige by association; and that in a symbolic interactions perspective; consumers may interpret symbols associated with a brand, which represent a socially shared meaning. Prestige brand concepts are more abstract than functional brand concepts, allowing prestige brands to accommodate a wider range of 
products that share few physical features (Hanzee \& Taghipourian, 2012; Monga \& John, 2010). These brands, because of their high prestige levels, fuel the consumer's self-concept, while brands that are simply function-oriented satisfy needs for product performance (Hanzee \& Taghipourian, 2012). Another difference between prestige brands and functional brands according to these authors may be found in the breadth and depth of their product mixes. Line extensions for prestige brands can more safely rely on brand prestige consistency, and may range considerably beyond their main brands in the features they possess (Hanzee \& Taghipourian, 2012).

Beyond these propositions, it is clear that much work need to be done in theory building with respect to prestige brands (Prince \& Davies, 2009). Even though the concept of prestige may mean different things to different consumers, the general assumption is that prestige brands are infrequently purchased, require a higher level of interest and strongly relate to an individual's self-concept (Hanzee \& Taghipourian, 2012). A consumer's perceived prestige towards a brand is created from a multitude of interactions between the consumer and various factors within the environment, hence it is expected that consumers would have different perceptions of prestige levels for the same brands (McCrackin, 1989). Consumers develop prestige meanings for brands based on interactions with people, object properties and hedonic values (Ergin \& Akbay, 2010). Associative learning theory details that celebrity endorsements influence brand image through a transfer of meaning (and prestige) from the endorser to the brand (Till, 1998); and communication activities establish a pattern of connectivity between the image of the celebrity and the image of the brand, as entities represent nodes in a cognitive network, whose connectivity can be modified according to experience.

McCracken (1989) and Kambitsis (2002) explained the effectiveness of celebrity endorsers by assessing the meanings consumers associate with the endorser and eventually transfer to the brand. McCracken (1989) developed a meaning transfer model that is composed of three stages. Firstly, the meaning associated with the celebrity moves from the endorser to the product or brand. Thus, meanings (and prestige) attributed to the celebrity become associated with the brand in the consumer's mind. Secondly, in the consumption process, the brand's meaning (and 
prestige) is acquired by the consumer. The third stage of the model explicitly shows the importance of the consumer's role in the process of endorsing brands with famous persons.

\section{Empirical Review}

Vipul (2011) in his study titled celebrity endorsement and its impact on sales, the study adopted survey research, studying 362 population. Among other findings, revealed that there exist a positive and significant relationship between celebrity's credibility and sale performance. Deshwal (2015) studied the impact of celebrity endorsement on sales of Guler Soft in Turkey. The research, which adopted descriptive research design, studied five (5) top soft drinks firms in Turkey who endorse celebrities in a quest to control the large proportion of the market. Findings from his study revealed that endorsed celebrity popularity influence sales performance of Guler. The study therefore recommended that Guler soft should maintain their brand endorsement program and that in the next phase of their endorsement, Guler should endorse those with more popularity base.

Pughazhendi and Ravindran (2012) in their work, "Influence of celebrity acceptability and consumers buying behaviour" showed that respondents are influenced by celebrity endorsed acceptance in terms of their buying decisions or product choice. Opuni (2014) later concluded in their study, "impact of brand ambassadors integrity and sales turn over Zentel Telecommunication, Zambia; that ambassador's intergrity has no significant impact on the sales turnover of Zentel Telecommunication. The study recommend that Zentel, should only endorse ambassadors with high social or endorsement profile and huge fan base regardless of their integrity status, as the core of their endorsement should be the target fan base and not their private life. Consequently, Khan (2016) clarified that by using celebrity physical appearance, trust worthiness, expertise and congruity on purchase intention is not enough to stimulate purchases in some market and most especially in Pakistan, as some consumers are brand loyal, their taste and choice options are not due to celebrity characteristics but due to their previous experience with product or service 


\section{Theoretical Framework}

\section{Source Effect Theory}

In Apejoye (2013), it was perceived that certain characteristics of a source (celebrity) can positively affect the consumers ${ }^{\text {ee }}$ attitude towards a product. This has been divided into two strands, namely: Source credibility and Source attractiveness.

In Apejoye (2013), it was perceived that certain characteristics of a source (celebrity) can positively affect the consumers ${ }^{\text {ee }}$ attitude towards a product. This has been divided into two strands namely: Source credibility and Source attractiveness. The Source credibility model explains that the acceptance and favorable response towards a product depends on the expertise, trustworthiness and knowledge about the celebrity. Goldsmith, Lafferty and Newell (2000) are also of the opinion that source credibility is the "extent to which the celebrity is perceived as possessing expertise relevant to the brand and can be trusted to deliver".

In a situation where the celebrity has considerable knowledge and expertise about the product, then the possibility of maximizing sales can be achieved (Ohanian, 1991). According to the source attractiveness model, the acceptance and response to a particular product by consumers is based on familiarity, likeability and similarity. McCracken (1989) further provides more insight to these concepts of familiarity, likeability and similarity. In this light, McCracken (1989) posits, "Familiarity refers to the knowledge consumers get about the celebrity through exposure in the media; likeability is the affection that celebrity enjoys as a result of the brand ambassador's physical appearance and/or behavior; and by similarity it is the supposed resemblance between celebrity and the targeted audience". Hence, the physical attractiveness of celebrities can elicit greater social response to a particular product (Apejoye, 2013).

\section{Methodology}

The study adopted survey research design, considering the research objectives of this study and associated problems. The population of study consist of all customers who consume Pepsi-Cola in Nasarawa State. Due to the nature of the population and the study in quest, the researcher conveniently selected 203 customers. Since the sample size is within the grip of the researcher, all the sampled consumer will be studied. 
Data for this study is primarily sourced using structured questionnaire on a five (5) likert scale. The instrument put to use for data collection is the multiple-choice questionnaire. The choice of this close-ended questionnaire was necessary because it generates higher response rate than its counterpart, the close ended type. And because of its simplicity and consistency, it was used to determine the opinion of consumers of Pepsi-Cola towards celebrity endorsement.

Questions asked on the questionnaire are in two segments, the closed ended question which are on five (5) likert scales and an open ended question which gives responds an opportunity to express their views on other issues that is not captured among the variables of the study.

Table 1. Reliability Tests of the Constructs

\begin{tabular}{|c|l|c|c|c|}
\hline SN & \multicolumn{1}{|c|}{ Variable } & N & Items & $\begin{array}{c}\text { Crombach } \\
\text { Alpha }\end{array}$ \\
\hline 1 & $\begin{array}{l}\text { Brand Ambassador's } \\
\text { Acceptance }\end{array}$ & 30 & 5 & .775 \\
\hline 2 & $\begin{array}{l}\text { Brand Ambassador's } \\
\text { Popularity }\end{array}$ & 30 & 2 & .721 \\
\hline 3 & $\begin{array}{l}\text { Brand Ambassador's } \\
\text { Credibility }\end{array}$ & 30 & 2 & .759 \\
\hline 4 & Brand ambassador's Integrity & 30 & 2 & .711 \\
\hline 5 & Sales Performance & 30 & 4 & .828 \\
\hline
\end{tabular}

Researcher's Computation, 2019

All Cronbach's value in this study are greater than 0.60 and thus prove that the study instrument is reliable. The construct shown in Table 1 above reflects five constructs of the study. However, fifteen (15) were raised across the five (5) constructs. The above analysis put that Cronbach's alpha value for Celebrity Acceptance construct at 0.775, for Brand Ambassador's Popularity construct at 0.721, for Brand Ambassador's Credibility construct at 0.759 , for Brand Ambassador's Integrity construct at 0.711 and for Sales Performance construct at 0.824 . This suggests that the study instrument is reliable and connotes that the internal consistency of this research is acceptable.

The primary data collected during the survey were analyzed with reference to research questions and formulated hypotheses. Descriptive statistics and inferential 
statistical methods were used to analyze the research questions and the formulated research hypotheses. Thus, percentage tables were used for descriptive statistics to analyse respondents' bio-data, while multiple regression analysis was the type of inferential statistics used for this study.

\section{Findings}

This section discusses data obtained from copies of questionnaire that were distributed and presented in tabular form for easy analyses and interpretation. Analyses were centered on brand ambassador's endorsement and sales performance. However, due to the magnitude of individual characteristics and attitude toward research and time constraint, a total of two hundred and three (203) copies of questionnaires were administered, out of which only one hundred and ninety three (193) copies were returned completed, valid for analysis and interpretation. Finally, regression analyses were carried out on the hypotheses of the study.

\section{Hypotheses Testing}

Regression Equation:

$\mathrm{Y}=\mathrm{a}+\beta \mathrm{x}$

$Y=a+\beta x(X 1, X 2, X 3, X 4)(2)$

Where:

$\mathrm{Y}=$ Dependent Variable is sales performance; $\mathrm{a}=$ Regression Constant;

$\beta=$ Beta coefficient or intercept or slope (i.e. it explains the actual effect of the independent variable);

$\mathrm{Xn}=$ The changing variable as $\mathrm{X} 1, \mathrm{X} 2, \mathrm{X} 3, \mathrm{X} 4$.

Where:

$\mathrm{X} 1=$ Brand Ambassador's Credibility (CC); X2= Brand Ambassador's Popularity (CP);

X3= Brand Ambassador's Acceptance (CA); X4= Brand Ambassador's Integrity (CI).

Final equation for study:

$\mathrm{SP}=$ Constant $+\beta(\mathrm{CC}, \mathrm{CP}, \mathrm{CA}, \mathrm{CI})(3)$

$\mathrm{Y}=\mathrm{a}+\beta 1 \mathrm{X} 1+\beta 2 \mathrm{X} 2+\beta 3 \mathrm{X} 3+\beta 4 \mathrm{X} 4 \ldots \ldots . \mathrm{BnXn}$

$\mathrm{Y}=0.22+0.17 \mathrm{X} 1,+0.14 \mathrm{X} 2,+0.16 \mathrm{X} 3,+0.48 \mathrm{X} 4$ 
It is evident from the equation that only Celebrity Integrity $(C I): \beta=.511 ; t(193)=10.935$, $\mathrm{P}(.000)<0.05$ contributes more significantly to Sales Performance $(\mathrm{CP})$. While others such as Celebrity Acceptance: $\beta=.131 ; \mathrm{t}(193)=2.760, \mathrm{P}(.000)<0.05$; Celebrity Popularity: $\beta=.166 ; \mathrm{t}(193)=2.036, \mathrm{P}(.000)<0.05$; and Celebrity Credibility: $\beta=.191$; $\mathrm{t}(193)=2.288, \mathrm{P}(.000)<0.05$ was not significant.

\section{Hypothesis One:}

Ho1: There is no significant relationship between brand ambassador's credibility and sales performance.

Table 2. Regression Analysis

\begin{tabular}{|c|c|c|c|c|}
\hline Model & R & R Square & Adjusted R Square & Std. Error of the Estimate \\
\hline 1 & $.961^{\mathrm{a}}$ & .924 & .923 & .22182 \\
\hline
\end{tabular}

a. Predictors: (Constant), Brand Ambassador's Credibility

\section{Anova}

\begin{tabular}{|c|l|c|c|c|c|c|}
\hline \multicolumn{2}{|c|}{ Model } & Sum of Squares & Df & Mean Square & F & Sig. \\
\hline \multirow{3}{*}{1} & Regression & 113.728 & 1 & 113.728 & 2311.313 & $.000^{\circ}$ \\
\cline { 2 - 8 } & Residual & 9.398 & 191 & .049 & & \\
\cline { 2 - 8 } & Total & 123.127 & 192 & & & \\
\hline
\end{tabular}

a. Dependent Variable: Sales Performance

b. Predictors: (Constant), Brand Ambassador's popularity

\section{Coefficientsa}

\begin{tabular}{|c|c|c|c|c|c|c|}
\hline \multirow{2}{*}{\multicolumn{2}{|c|}{ Model }} & \multicolumn{2}{|c|}{ Unstandardized Coefficients } & \multirow{3}{*}{$\begin{array}{c}\text { Standardized Coefficients } \\
\text { Beta } \\
\end{array}$} & \multirow{2}{*}{$\mathrm{T}$} & \multirow{2}{*}{ Sig. } \\
\hline & & $B$ & Std. Errol & & & \\
\hline \multirow{2}{*}{1} & (Constant) & -1.056 & .105 & & -10.040 & .000 \\
\hline & Celebrity Credibility & 1.279 & .027 & .961 & 48.076 & .000 \\
\hline
\end{tabular}

a. Dependent Variable: Sales Performance

\section{Interpretation of Results}

$\mathrm{Y}=\mathrm{a}+\beta(\mathrm{X} 1), \mathrm{SP}=\mathrm{a}+\beta(\mathrm{CC})$

The above regression table shows the result of hypothesis one, that Brand Ambassador's credibility does not have significant impact on sales performance. However, the tables reveal that there is a high level of fitness at $R$ value of $0.961, R_{2}$ of 0.924 and F-value of 2311.313 . The $\mathrm{R}_{2}$ of 0.924 connotes that about $92.4 \%$ of the variation in sales performance can be explained by Brand Ambassador's credibility while $7.6 \%$ remains unexplained by the regression model. However, the $R$ value of 0.961 in the table indicates a strong and positive relationship between the two variables (i.e. Brand Ambassador's credibility and sales performance), which also helps to confirm a correlation results. Since the F-sig. (p-value) of .000 $<0.05$. Hence, 
there exist a significant relationship between Brand Ambassador's credibility and sales performance, this agrees with the study of (Vipul, 2011) whose findings revealed a positive and significant relationship between celebrity's credibility and sale performance. The null hypothesis previously advanced that Brand Ambassador's credibility does not have significant impact on sales performance is hereby rejected.

\section{Hypothesis Two:}

$\mathbf{H o}_{1}$ : There is no significant relationship between Brand Ambassador's popularity and sales performance.

Table 3: Regression Analysis ANOVAModel Summary

\begin{tabular}{|c|c|c|c|c|}
\hline Model & R & R Square & Adjusted R Square & Std. Error of the Estimate \\
\hline 1 & $.978^{\mathrm{a}}$ & .956 & .956 & .16775 \\
\hline
\end{tabular}

a. Predictors: (Constant), Brand Ambassador's popularity

\section{ANOVA}

\begin{tabular}{|c|c|c|c|c|c|c|}
\hline \multicolumn{2}{|c|}{ Model } & Sum of Squares & df & Mean Square & F & Sig. \\
\hline \multirow{3}{*}{1} & Regression & 117.752 & 1 & 117.752 & 4184.708 & $.000^{\circ}$ \\
\cline { 2 - 8 } & Residual & 5.374 & 191 & .028 & & \\
\cline { 2 - 8 } & Total & 123.127 & 192 & & & \\
\hline
\end{tabular}

a. dependent variable sales performance

Coefficientsa

\begin{tabular}{|c|c|c|c|c|c|c|}
\hline \multirow{2}{*}{\multicolumn{2}{|c|}{ Model }} & \multicolumn{2}{|c|}{ Unstandardized Coefficients } & Standardized Coefficients & \multirow{2}{*}{$\mathrm{T}$} & \multirow{2}{*}{ Sig. } \\
\hline & & $B$ & Std. Error & Beta & & \\
\hline \multirow{2}{*}{1} & (Constant) & .783 & .050 & & 15.559 & .000 \\
\hline & Celebrity Popularity & .830 & .013 & .978 & 64.689 & .000 \\
\hline
\end{tabular}

a. dependent variable: sales performance

Interpretation of Results

$\mathrm{Y}=\mathrm{a}+\beta(\mathrm{X} 2), \mathrm{SP}=\mathrm{a}+\beta(\mathrm{CP})$

The above regression tables show the result of hypothesis two, that brand ambassador's popularity does not have significant impact on sales performance. However, the tables reveal that there is a high level of fitness at $R$ value of $0.978, R_{2}$ of 0.956 and F-value of 4184.708 . The $\mathrm{R}_{2}$ of 0.956 connotes that about $95.6 \%$ of the variation in sales performance can be explained by brand ambassador's popularity while $4.4 \%$ remains unexplained by the regression model. However, the $\mathrm{R}$ value of 0.978 in the table indicates a strong and positive relationship between the two variables (i.e. brand ambassador's popularity and sales performance), which also helps to confirm a correlation results. Since the F-sig. (p-value) of .000<0.05. Hence, there exist a significant relationship between which also helps to confirm a correlation 
results. Since the F-sig. (p-value) of $.000<0.05$. Hence, there exist a significant relationship between which also helps to confirm a correlation results. Since the F-sig. (p-value) of $.000<0.05$. Hence, there exist a significant relationship between which also helps to confirm a correlation results. Since the F-sig. (p-value) of $.000<0.05$. Hence, there exist a significant relationship between which also helps to confirm a correlation results. Since the F-sig. (p-value) of $.000<0.05$. Hence, there exist a significant relationship between which also helps to confirm a correlation results. Since the F-sig. (p-value) of $.000<0.05$. Hence, there exist a significant relationship between which also helps to confirm a correlation results. Since the F-sig. (p-value) of $.000<0.05$. Hence, there exist a significant relationship between which also helps to confirm a correlation results. Since the F-sig. (p-value) of .000<0.05. Hence, there exist a significant relationship between which also helps to confirm a correlation results. Since the F-sig. (p-value) of $.000<0.05$. Hence, there exist a significant relationship between which also helps to confirm a correlation results. Since the F-sig. (p-value) of $.000<0.05$. Hence, there exist a significant relationship between which also helps to confirm a correlation results. Since the F-sig. (p-value) of $.000<0.05$. Hence, there exist a significant relationship between brand ambassador's popularity and sales performance, this findings agrees with the findings of Deshwal (2015) whose Findings that endorsed celebrity popularity influence sales performance of Guler whilst the null hypothesis previously advanced that brand ambassadors popularity does not have significant impact on sales performance is hereby rejected.

Ho.: There is no significant relationship between brand ambassador's acceptance and sales performance of Pepsi Cola, whilst the null hypothesis previously advanced that brand ambassador's acceptance does not have significant impact on sales performance is hereby rejected. 
Table 4. Regression Analysis

Model Summary

\begin{tabular}{|c|c|c|c|c|}
\hline Model & R & R Square & Adjusted R Square & Std. Error of the Estimate \\
\hline 1 & $.978^{\mathrm{a}}$ & .956 & .956 & .16768 \\
\hline
\end{tabular}

a. Predictors: (Constant), Celebrity acceptance

Anova

\begin{tabular}{|c|l|c|c|c|c|c|}
\hline \multicolumn{2}{|c|}{ Model } & Sum of Squares & df & Mean Square & F & Sig. \\
\hline \multirow{3}{*}{1} & Regression & 117.752 & 1 & 117.752 & 4188.077 & $.000^{\circ}$ \\
\cline { 2 - 8 } & Residual & 5.370 & 191 & .028 & & \\
\cline { 2 - 8 } & Total & 123.127 & 192 & & & \\
\hline
\end{tabular}

a. dependent variable: Sales Performance

b. Predicators: (Constant) Brand Ambassador's Acceptability

\begin{tabular}{|c|c|c|c|c|c|c|}
\hline \multirow{2}{*}{\multicolumn{2}{|c|}{ Model }} & \multicolumn{2}{|c|}{ Unstandardized Coefficients } & \multirow{2}{*}{$\begin{array}{c}\text { Standardized Coefficients } \\
\text { Beta }\end{array}$} & \multirow[b]{2}{*}{$\mathrm{T}$} & \multirow{2}{*}{ Sig. } \\
\hline & & $B$ & Std. Error & & & \\
\hline \multirow{2}{*}{1} & (Constant) & .767 & .051 & & 15.180 & .000 \\
\hline & Celebrity Acceptance & 829 & .013 & .978 & 64.715 & .000 \\
\hline
\end{tabular}

a. Dependent Variable: Sales Performance

Interpretation of Results

$\mathrm{Y}=\mathrm{a}+\beta(\mathrm{X} 3), \mathrm{SP}=\mathrm{a}+\beta(\mathrm{CA})$

The above regression tables show the result of hypothesis three, that brand ambassador's acceptance does not have significant impact on sales performance. However, the tables reveal that there is a high level of fitness at $R$ value of $0.978, R_{2}$ of 0.956 and F-value of 4188.077 . The $\mathrm{R}_{2}$ of 0.956 connotes that about $95.6 \%$ of the variation in sales performance can be explained by brand ambassador's acceptance while $4.4 \%$ remains unexplained by the regression model. However, the $\mathrm{R}$ value of 0.978 in the table indicates a strong and positive relationship between the two variables (i.e. brand ambassador's acceptance and sales performance), which also helps to confirm a correlation results. Since the F-sig. (p-value) of .000<0.05. Hence, there exist a significant relationship between brand ambassador's acceptance and sales performance, this agrees with the findings of Pughazhendi and Ravindran (2012) whose findings showed that respondents are influenced by endorsed celebrity acceptance in terms of their buying decisions or product choice, whilst the null hypothesis previously advanced that brand ambassador's acceptance does not have significant impact on sales performance is hereby rejected. 


\section{Hypothesis Four:}

Ho4: Brand ambassador's integrity does not have significant impact on sales performance.

Table 5. Regression Analysis

Model Summary

\begin{tabular}{|c|c|c|c|c|}
\hline Model & R & R Square & Adjusted R Square & Std. Error of the Estimate \\
\hline 1 & $.981 \mathrm{a}$ & .963 & .963 & .15389 \\
\hline
\end{tabular}

ANOVA

\begin{tabular}{|l|l|l|l|l|l|l|}
\hline \multicolumn{2}{|l|}{ Model } & Sum of Squares & df & Mean Square & F & Sig. \\
\hline \multirow{4}{*}{1} & Regression & 118.603 & 1 & 118.603 & 5007.982 & $.000^{\circ}$ \\
\cline { 2 - 8 } & Residual & 4.523 & 191 & 024 & & \\
\cline { 2 - 8 } & Total & 123.127 & 192 & & & \\
\hline
\end{tabular}

a. Dependent Variable: Sales Performance

b. Predictors: (Constant), Celebrity integrity

\begin{tabular}{|c|l|c|c|c|c|c|}
\hline \multicolumn{2}{|c|}{ Model } & \multicolumn{2}{c|}{ Unstandardized Coefficients } & Standardized Coefficients & \multirow{2}{*}{ T } & \multirow{2}{*}{ Sig. } \\
\cline { 3 - 7 } \multicolumn{2}{|c|}{} & B & Std. Error & Beta & 6.105 & .000 \\
\hline \multirow{2}{*}{1} & (Constant) & .320 & .052 & & 70.767 & .000 \\
\cline { 2 - 7 } & Celebrity Integrity & .917 & .013 & .981 & & \\
\hline
\end{tabular}

a. Dependent Variable: Sales Performance

Interpretation of Results

$\mathrm{Y}=\mathrm{a}+\beta(\mathrm{X} 4), \mathrm{SP}=\mathrm{a}+\beta(\mathrm{CI})$

The above regression tables show the result of hypothesis four, that brand ambassador's integrity does not have significant impact on sales performance. However, the tables reveal that there is a high level of fitness at $R$ value of $0.981, R_{2}$ of 0.963 and F-value of 5007.982 . The $\mathrm{R}_{2}$ of 0.963 connotes that about $96.3 \%$ of the variation in sales performance can be explained by brand ambassador's integrity while $3.7 \%$ remains unexplained by the regression model. However, the $R$ value of 0.981 in the table indicates a strong and positive relationship between the two variables (i.e. brand ambassador's integrity and sales performance), which also helps to confirm a correlation results. Since the F-sig. (p-value) of .000 $<0.05$. Hence, there exist a significant relationship between brand ambassador's integrity and sales performance, this findings disagree with the findings of Opuni (2014) whose findings revealed that ambassador's integrity has no significant impact on the sales turnover of Zentel Telecommunication. 


\section{Discussion of Findings}

The findings from this study confirm the significant effects that exist between celebrity integrity, popularity and acceptance as a measure of celebrity endorsement and sales performance. But not leaving out Brand ambassador's credibility because it appears to be the lowest compared to other constructs that were researched in this study. Thus, this finding corroborates with the studies of (Vipul, 2011; Deshwal, 2015; Pughazhendi \& Ravindran, 2012; Oyeniyi, 2014; Patel, 2015; Giridhar, 2012)

Out of the 193 questionnaires retrieved, 53 respondents posited on the open ended section of the questionnaire that even though brand ambassadorship enhance firms' sales performance, firms like Pepsi-cola trailing market leaders like Coca Cola should maintain less promotional focus on brand ambassadorship endorsement, due to high costs compared to other forms of advertisement.

\section{Conclusions/Recommendation}

Celebrity endorsement can be a truly profitable promotional tool for consumer goods and most especially Pepsi-cola in Nigeria market. Based on the outcome of test of hypotheses through regression analysis, the dimensions and features of celebrity endorsement used in this study are all significant. Thus, Pepsi-Cola should pay more attention to celebrity integrity, popularity, acceptance and credibility when deciding on the choice of celebrity endorsers. Firms should also realize that the brand should be bigger than the celebrity itself, otherwise the celebrity endorser will overshadow the product itself to the point of making the brand obsolete and its purpose defeated, especially in the event of a dispute.

Based on the findings from the open ended section of the questionnaire, as captured on the last paragraph of the discussion of findings, the study therefore, suggests that Pepsi should invest heavily on other promotional and advertising platforms that will root their product deep in the market, and give very little attention to brand ambassadorship, since their operation is struggling with fierce competition from the market leader (Cocacola) and other upcoming firms with aggressive marketing strategies. 


\section{References}

Adedayo, D.A. (2006). Understanding of statistical methods, Ibadan, Grace Springs Publishers.

Apejoye, J.A. (2013) Influence of Celebrity Endorsement of Advertisement on Students ${ }^{\text {ee }}$ Purchase Intention, Mass Communication and Journalism, 3(3).

Arifeen, N. U., Hussain, M., Kazmi, S., Mubin, M., Latif, S., \& Qadri, W. (2014). Measuring Business Performance: Comparison of Financial, Non Financial and Qualitative Indicators. European Journal of Business and Management, 6(4), $38-45$

Amos, C., Holmes, G., \& Strutton, D. (2008). Exploring the relationship between celebrity endorser effects and advertising effectiveness: A quantitative synthesis of effect size. International Journal of Advertising, 27(2), 209-234.

Aaker, D. A. (1996). Building strong brands. New York: Free Press.

Aaker, D. A. (1991). Managing brand equity. New York: Free Press.

Aaker, D. A., \& Shansby, J. G. (1982). Positioning your product. Business Magazine, $4(1), 63-68$.

Aaker, D. A., \& Myers, J. (1987). Advertising management. 3rd Edition. Englewood Cliffs, New Jersey: Prentice Hall.

Aaker, J. L. (1997, August). Dimensions of brand personality. Journal of Marketing Research, 34, 347-356.

Aaker, J. L. (1999). The malleable self: The role of self-expression in persuasion. Journal of Marketing Research, 36, 45-57.

Aaker, D. A., Kumar, V., \& Day, G. S. (2007). Marketing research. 9th Edition. NJ: John Wiley and sons Inc.

Banytė, J., Stonkienè, E. \& Piligrimienè, Z. (2011). Selecting Celebrities in Advertising: The Case of Lithuanian Sports Celebrity in Non Sport Product Advertisement. Economics and Management, 16, 1215-1224

Bhasin, H. (2018). Celebrity marketing; https://www.marketing91.com/celebritymarketing/

Dean, D.H. \& Biswas, A. (2001) „Third- Party Organization Endorsement of Products: An Advertising Cue Affecting Prepurchase Evaluation of Goods and Services ${ }^{e e}$, Journal of Advertising, 30(4), 41-57. 
Deshwal, P. (2015).Impact of celebrity endorsement on sales, International Journal of Advanced Research in Management and Social Sciences, 4(12).

Erdogan, B. Z. (1999), „Celebrity Endorsement: A Literature Reviewe, Journal of Marketing Management, 15, 291-314.

Erdogan, B.Z., Baker, M.J. \& Tagg, S. (2001) „Selecting Celebrity Endorses: The Practitionere's Perspective ee, Journal of Advertising Research, 41(3), 39-48.

Ericsson, L. \& Hakansson, E. (2005), „Athletes as Celebrity Endorsers: Case Studies from Sweden"e, Lulea University of Technology, Sweden. Available at: http://www.epubl.ltu.se

Goldsmith, E.R., Lafferty, A.B., \& Newell, J.S. (2000). The Impact of Corporate Credibility and Celebrity. International Journal of Social Sciences, 4(12), 11-19.

Keller, K. L. (2003). Understanding brands, branding, and brand equity. Interactive Marketing, 5(1), 7-20.

Opuni, F.F., Asiedu, K.A \& Acheampong, I. (2014). The Effect of Celebrity Endorsement on Product Purchase: The Case of Fan Milk,

Pughazhendi, A. \& Ravindran, D.S. (2012) A study on the influence of using celebrity endorsements on consumer buying behaviour in Tamil Nadu, India; Journal of Research in International Business Management, 2(4), 89-96.

Vipul, J. (2011). Celebrity Endorsement And Its Impact On Sales: A Research Analysis Carried Out In India, Global Journal of Management and Business Research, 11(4). 